\title{
UJI AKTIVITAS ANTIHIPERURISEMIA EKSTRAK ETANOL TUMBUHAN SURUHAN (Peperomia pellucida L.Kunth) TERHADAP TIKUS PUTIH JANTAN (Gallur wistar) YANG DI INDUKSI KAFEIN
}

\author{
Agista C. Imbar ${ }^{1)}$, Edwin de Queljoe ${ }^{1)}$, Henki Rotinsulu ${ }^{1)}$ \\ ${ }^{1)}$ Program Studi Farmasi FMIPA UNSRAT Manado, 95115
}

\begin{abstract}
Pepper elder plant (Peperomia pellucida L.Kunth) is one of the plants that has the potential to cure various diseases, one of which is to reduce blood uric acid levels. The order contains chemical compounds namely flavonoids and saponins whose mechanism of action inhibits the activity of xantin oxsidase. The aim of this study was to determine the antihyperurismic activity of ethanol extracts of pepper elder plants (Peperomia pellucida L.Kunth) aginst male white rats wistar strain induced with caffeine. This research is experimental. Fifteen rats were divided into 5 treatment groups; each group consisted of 3 rats. The first group was the negative control $\left(K^{-}\right)$given $C M C$ suspension, the second group was positive control $\left(\mathrm{K}^{+}\right)$given allopurinol, the three groups were 50mg dose variation groups, the four groups were $100 \mathrm{mg}$ dose variation groups, and the five groups were variations a dose $200 \mathrm{mg}$. The rats were examined their fasting uric acid levels, then rats were induced by caffeine at dose $300 \mathrm{mg} / \mathrm{kgBW}$. Orally. On the 6th day the uric acid level was examined and then treated according to the group for 9 days, the measurement of uric acid levels was done 3 days. The data obtained were then analyzed statistic using SPSS. Includes test (Levene), test (One sample kolmogrove smirnov-test), ANNOVA, kruskall wallis test. The results showed that the ethanolic extract of the pepper elder plant (Peperomia pellucida L.Kunth) could have a great effect on reducing hyperuricemia at a dose $200 \mathrm{mg}$.
\end{abstract}

Keywords: Antihyperuricemia, Peperomia pellucida L.Kunth.

\section{ABSTRAK}

Suruhan (Peperomia pellucida L.Kunth) merupakan salah satu tanaman yang berpotensi untuk menyembuhkan berbagai penyakit, salah satunya adalah dapat menurunkan kadar asam urat darah. Suruhan mengandung senyawa kimia yaitu flavonoid dan saponin yang mekanisme kerjanya menghambat aktivitas Xantin Oksidase. Penelitian ini bertujuan untuk mengetahui aktivitas Antihiperurisemia ekstrak etanol tumbuhan suruhan (Peperomia pellucida L.Kunth) terhadap tikus putih jantan galur wistar yang di induksi kafein. Penelitian ini bersifat eksperimental. 15 ekor tikus dibagi ke dalam 5 kelompok perlakuan masing- masing kelompok terdiri dari 3 ekor tikus. Kelompok pertama kelompok Kontrol negatif $\left(\mathrm{K}^{-}\right)$yang diberikan suspensi $\mathrm{CMC}$, Kelompok kedua kontrol positif $\left(\mathrm{K}^{+}\right)$yang diberikan allopurinol, kelompok tiga kelompok variasi dosis $50 \mathrm{mg}$, kelompok empat kelompok variasi dosis $100 \mathrm{mg}$, dan kelompok lima kelompok variasi dosis $200 \mathrm{mg}$. Sebelumnya tikus dilakukan pemeriksaan kadar asam urat puasa, selanjutnya tikus diinduksi kafein dosis $300 \mathrm{mg}$. secara oral. Pada hari ke 6 diperiksa kadar asam urat kemudian dilakukan perlakuan sesuai kelompok selama 9 hari, pengukuran kadar asam urat dilakukan 3 hari sekali. Data yang diperoleh kemudian dianalisis secara statistik menggunakan SPSS. Meliputi uji (Levene), uji (One-Sample kolmogorove Smirnov-test), ANNOVA, uji kruskall wallis. Hasil penelitian menunjukan bahwa ekstrak etanol tumbuhan Suruhan (Peperomia pellucida L.Kunth) dapat memberikan efek penurunan Hiperurisemia yang besar pada dosis $200 \mathrm{mg}$

Kata kunci: Antihiperurisemia, Peperomia pellucida L.Kunth. 


\section{PENDAHULUAN}

Penyakit asam urat atau Gout merupakan penyakit kronis degeneratif, dapat disebabkan karena adanya perubahan gaya hidup tidak sehat seperti pola makan yang tidak sehat dalam masyarakat yang banyak mengndung protein tinggi, terutama protein hewani yang banyak mengandung purin.

Pengobatan pada Hiperurisemia adalah dengan memberikan obat yang dapat menurunkan kadar asam urat atau yang dapat menghambat pembentukan asam urat dalam tubuh seperti pemberian urikusorik dan allopurinol. Namun penggunaan obat-obatan sintetik dalam jangka panjang dapat menimbulkan masalah baru yang merugikan dan berbahaya, seperti pada penggunaan allopurinol dalam jangka waktu lama dapat menimbulkan gangguan pada kulit, lambung, usus, gangguan darah dan interstitial nefritis akut (Taringan, et al. 2012).

Dewasa ini telah banyak dilakukan penelitian untuk mengembangkan alterntif pengobatan pada penyakit hiperurisemia menggunakan tanaman yang dapat membantu menurunkan atau mengurangi kadar asam urat dalam darah. Diantara tanaman yang di teliti tersebut diataranya adalah tanaman herba Suruhan (Peperomia pellucida L.Kunth). Penggunaan herba Suruhan sebagai obat juga dilakukan oleh masyarakat mancanegara. Dintaranya digunakan untuk menghentikan pendarahan oleh masyarakat Bolivia, yaitu suku indian altenos. Di Brazil utara, herba suruhan banyak digunakan untuk menurunkan kadar kolesterol dalam darah. Di Guyana kehidupan manusia, yaitu sebagai antikanker, antiinflamasi, dan antimikroba (Khoeri, 2009). Berdasarkan pengalaman empiris dalam menggunakan herba suruhan sebagai pengobatan, penelitian mengenai suruhan mulai banyak dilakukan, beberapa penelitian tersebut menunjukan aktivitas Suruhan sebagai antioksidan, anti diabetes, abses, bisul, radang kulit, penyakit ginjal, luka bakar atu memar, dan anti kanker. Maka penelitian ini dilakukan untuk mengetahui apakah ekstrak etanol herba suruhan dapat menurunkan kadar asam urat darah tikus jantan galur wistar (Rattus norvegicus) yang diinduksi kafein. Pemilihan Hewan Uji tikus galur wistar karena tikus memiliki ketahanan perlakuan. Sebagai pembanding efektivitas ekstrak dalam menurunkan kadar asam urat darah maka digunakan obat sintetik standar seperti allopurinol. Untuk mengetahui aktivitas penurunan kadar asam urat serum darah, maka digunakan metode pengujian menggunakan metode tes strip asam urat.

\section{METODOLOGI PENELITIAN}

\section{Waktu dan Tempat \\ Penelitian}

Penelitian dilaksanakan di laboratorium lanjutan Universitas Sam Ratulangi Manado. Pada Bulan juli sampai agustus 2019.

\section{Bentuk Penelitian}

Penelitian ini dilakukan dengan desain eksperimental. Penelitian ini dilakukan untuk mengetahui aktivitas antihiperurisemia ekstrak etanol dari tumbuhan Suruhan (Peperomia pellucida L.Kunth) terhadap tikus putih jantan yang telah di buat hiperurisemia. Dalam 
penelitian ini obat yang digunakan sebagai pembanding kelompok uji adalah allopurinol

\section{Alat dan Bahan}

Alat

Alat yang digunakan dalam penelitian ini Alat-alat yang digunakan pada penelitian ini adalah alat tes strip penguji asam urat (Easytouch GCU), sonde oral, spuit, jarum suntik, timbangan hewan, timbangan analitik, kandang tikus, blender, vacuum rotary evaporator, hotplate, oven, kertas saring, kapas, batang pengaduk, spatula, lumpang, alu, aluminium foil dan alat-alat gelas.

\section{Bahan}

Bahan Kimia yang digunakan pada penelitian ini adalah etanol 96\%, kafein, $\mathrm{CMC}$, aquades. Bahan uji yang digunakan dalam penelitian ini adalah simplisia herba suruhan (Peperomia pellucida L.Kunth). Tumbuhan diperoleh dari pekarangan rumah warga yang tumbuh liar di kelurahan Taratara 1 Kota Tomohon. Serta allopurinol sebagai pembanding yang diperoleh dari apotek di daerah Kota Manado.

\section{Prosedur Penelitian}

\section{Pengolahan Bahan Uji}

Tumbuhan Suruhan (Peperomia

Pellucida L.Kunth) segar 7000 g dikeringkan dengan cara di oven pada suhu $50^{\circ} \mathrm{C}$ sampai menjadi simplisia. Tumbuhan suruhan yang telah dikeringkan dan telah menjadi simplisia kemudian diserbukan dengan cara di blender.

\section{Pembuatan Ekstrak Etanol}

Penelitian ini menggunakan ekstrak etanol campuran dari akar, batang dan daun tumbuhan suruhan. Pada penelitian ini tumbuhan suruhan diekstraksi dengan etanol 96\%. Pembuatan ekstrak tumbuhan suruhan dilakukan dengan metode maserasi, yaitu serbuk tumbuhan Suruhan ditimbang sebanyak $300 \mathrm{~g}$ lalu diekstraksi dengan menggunakan 1,5 L etanol dengan cara maserasi selama 3 hari. Ekstrak kemudian disaring dengan menggunakan kertas saring (filtrat 1) dan sisanya diekstrak kembali selama 2 hari menggunakan 600 $\mathrm{mL}$ etanol lalu disaring (filtrat 2). Selanjutnya filtrat 1 dan 2 digabungkan, diuapkan dengan rotary evaporator pada suhu $70^{\circ} \mathrm{C}$ dan dilanjutkan dengan pengeringan di oven pada suhu $40^{\circ} \mathrm{C}$ sampai menjadi ekstrak kental.

\section{Pembuatan Larutan Kafein}

Sebanyak 60 mg/200grBB. Kafein dilarutkan ke dalam aquades sebanyak 1 $\mathrm{mL}$.

\section{Pembuatan Larutan Allopurinol}

Sebanyak 5,4 mg allopurinol dilarutkan ke dalam CMC 0,5\% sebanyak $1 \mathrm{~mL}$.

\section{Pembuatan Larutan Ekstrak Tumbuhan Suruhan Dosis 50; 100; 200mg}

Ekstrak tumbuhan suruhan diberikan secara oral pada tikus wistar. Dosis yang digunakan dalam penelitian ini adalah dosis 50; 100; $200 \mathrm{mg}$. Dengan faktor konversi dosis manusia ke tikus adalah 0,018, maka dosis yang akan diberikan pada tikus; Dosis 50 sebanyak 
$0,9 \mathrm{mg}$; Dosis 100 sebanyak $1,8 \mathrm{mg}$; Dosis 200 sebanyak 3,6 mg.

Banyaknya ekstrak tumbuhan suruhan yang akan di gunakan kemudian di larutkan dalam CMC 0,5\% sebanyak $1 \mathrm{~mL}$ dan di induksi pada masing-masing tikus.

\section{Pengujian Efek Ekstrak Etanol Tumbuhan Suruhan terhadap Kadar Asam urat Tikus}

Hewan uji dipilih sebanyak 15 ekor tikus putih jantan secara acak dan dibagi dalam 5 kelompok dengan jumlah masing-masing kelompok terdiri dari 3 ekor .

Sebelum pengujian tikus dikelompokkan menjadi 5 kelompok dengan jumlah masing-masing kelompok 3 ekor, kemudian tikus dipuasakan terlebih dahulu selama 8 jam dengan tidak diberi makan tetapi tetap diberi minum (Taringan. 2012). Selanjutnya dilakukan pengukuran kadar asam urat puasa pada masing-masing kelompok perlakuan . Setelah didapat hasil pengukuran kadar asam urat. Selanjutnya tikus diberikan induksi suspensi kafein sebagai upaya peningkatan kadar asam urat darah. Kemudian diukur kadar asam urat setelah 6 hari pemberian kafein untuk melihat peningkatannnya. Setelah diinduksi tikus diistirahatkan dalam kandang masingmasing dan diberi makan dan minum. Setelah 6 hari dilakukan induksi dan telah diiukur kadar asam urat darah pada tikus, kemudian masing-masing kelompok tikus diberi perlakuan sesuai kelompoknya selama 9 hari. Pengukuran kadar asam urat selama perlakuan dilakukan setiap tiga hari sekali (Azizahwati et al. 2005). Menggunakan strip asam urat dan pengambilan darah melalui vena ekor tikus (Taringan et al. 2012)

\section{Pengolahan Data}

Data yang diperoleh kemudian dianalisis secara statistic menggunakan SPSS. Pengolahan data yang di lakukan adalah dengan menguji homogenitas data seluruh kelompok uji (Levene), dilanjutkan dengan uji kenormalan data (One-Sample kolmogorove Smirnov-test) dan dilanjutkan dengan analisis varian (ANNOVA), di lanjutkan dengan uji kruskall wallis untuk mengetahui ada tidaknya perbedaan secara bermakna antar kelompok hewan uji.

\section{HASIL DAN PEMBAHASAN}

\section{Ektraksi Sampel}

Dari 7000 gram berat basah tumbuhan herba Suruhan (Peperomia pellucida L.Kunth) di dapatkan 300 gram serbuk simplisia kemudian di ekstraksi dengan pelarut etanol $96 \%$ selama 5 hari dan diperoleh 22,4 gram ekstrak kental etanol herba Suruhan (Peperomia pellucida L.Kunth). Ekstraksi herba Suruhan (Peperomia pellucida L.Kunth) dilakukan dengan cara maserasi meggunakan pelarut Etanol. Prinsip dari ekstraksi sendiri yaitu penarikan senyawasenyawa dalam tanaman oleh pelarut yang sesuai dari segi kepolarannya. Pelarut yang digunakan dalam penelitian ini adalah pelarut Etanol 96\%. Etanol digunakan sebagai pelarut karena etanol bersifat Polar, Universal, yang dapat melarutkan metabolit sekunder dari berbagai tingkat polaritas (Hakim, 2012). 


\section{Pengujian Efek Ekstrak Etanol Tumbuuhan Suruhan terhadap kadar Asam urat tikus} seluruh kelompok tikus dipuasakan selama 8 jam tanpa diberi makan tetapi tetap diberi minum, Fahri (2004), menyatakan bahwa sebelum pengambilan darah tikus perlu dipuasakan selama 8-14 jam, hal ini bertujuan agar tidak terjadi perubahan kadar asam urat serum karena asupan makanan. Kemudian dilakukan pengukuran kadar asam urat puasa pada seluruh kelompok uji. Selanjutnya seluruh kelompok uji diinduksi kafein dengan dosis 300mg/kgBB. Kafein digunakan sebagai penginduksi asam urat karena kafein mengandung metilxanthin yang mengalami eliminasi melalui hati dan diekskresikan melalui urin dalam bentuk asam urat. Kafein dapat meningkatkan kadar asam urat dengan adanya gugus metil yang akan dioksidasi oleh enzim xanthin oksidase membentuk asam urat dalam tubuh (Artini, et al 2012).

Setelah tikus mengalami hiperurisemia, pada hari ketujuh semua tikus diberi perlakuan sesuai kelompok. Kelompok I kontrol negatif diberikan CMC, Kelompok II kontrol positif diberikan allopurinol 5,4 mg, Kelompok III, IV, V merupakan kelompok bahan uji dengan dosis $50 \mathrm{mg}, 100 \mathrm{mg}, 200 \mathrm{mg}$. Pemberian bahan uji selama 9 hari setelah tikus hiperurisemia.

Hasil Pengukuran kadar asam urat darah tikus seluruh kelompok hewan uji selama percobaan yang dilakukan selama 15 hari. Pengukuran kadar asam urat darah pada tikus uji dilakukan sebanyak lima kali yaitu sebelum di induksi kafein yang merupakan kadar asam urat puasa,
Setelah di induksi kafein $300 \mathrm{mg} / \mathrm{kgBB}$, selanjutnya pengukuran kadar asam urat setelah diberi perlakuan sesuai kelompok pada hari ke tiga perlakuan (Hari ke-3), hari ke enam perlakuan (Hari ke-6), dan hari ke sembilan perlakuan (Hari ke-9).

Darah dimbil dengan melukai bagian yang terdapat pembuluh vena pada ekor tikus, kemudian darah di teteskan pada tes strip, tunggu beberapa detik sampai kadar asam urat darah tikus tampil pada layar alat (Azizahwati, 2005). Kondisi hiperurisemia pada hewan uji dicapai dengan cara semua tikus diinduksi larutan kafein dengan dosis $300 \mathrm{mg} / \mathrm{kgBB}$ selama 6 hari.

Tabel 1. Kadar Asam Urat Tikus sebelum dan sesudah pemberian Kafein

\begin{tabular}{ccc}
\hline Kelompok & $\begin{array}{l}\text { Kadar } \\
\text { Asam Urat } \\
\text { Puas }\end{array}$ & $\begin{array}{c}\text { Kadar Asam } \\
\text { Urat setelah } \\
\text { pemberian } \\
\text { Kafein }\end{array}$ \\
\hline $\begin{array}{c}\text { Kontrol } \\
\text { negatif }\end{array}$ & 3.10 & 5.70 \\
\hline Kontrol positif & 2.73 & 7.27 \\
\hline Dosis 50 & 2.87 & 6.07 \\
\hline Dosis 100 & 3.13 & 6.67 \\
\hline Dosis 200 & 2.90 & 5.47 \\
\hline
\end{tabular}


Tabel 1 menjelaskan bahwa kadar asam urat puasa tikus, berada pada keadaan normal dengan rata-rata 2,73$3,13 \mathrm{mg} / \mathrm{dL}$. Kadar asam urat darah 3,37 $\mathrm{mg} / \mathrm{dl}$, sedangkan pada tikus betina sebesar 0,24-2,92 mg/dl (Aryadi, 2017). Untuk hasil pengkuran kadar asam urat setelah pemberian kafein, menunjukan bahwa rata-rata kadar asam urat seluruh kelompok uji mengalami kenaikan pada hari ke 6 yaitu antara 5,47-7,27 mg/dL. Hal ini menunjukan bahwa pengkondisian hiperurisemia berhasil dilakukan.

Tabel 2. Kadar Asam Urat Tikus selama pemberian perlakuan

\begin{tabular}{cccc}
\hline Kelompok & \multicolumn{3}{c}{ Hari Ke } \\
\hline & $\mathbf{9}$ & $\mathbf{1 2}$ & $\mathbf{1 5}$ \\
\hline $\begin{array}{c}\text { Kontrol } \\
\text { Negaif }\end{array}$ & 5,33 & 5,20 & 5,00 \\
Kontrol & 2,83 & 2,33 & 2,17 \\
Positif & & & \\
Dosis 50 & 3,33 & 2,77 & 2,57 \\
Dosis 100 & 3,40 & 3,27 & 2,87 \\
\hline Dosis 200 & 3,27 & 2,60 & 2,30 \\
\hline
\end{tabular}

Kusmiyati (2008), menyatakan bahwa peningkatan kadar asam urat tikus tergantung pada kondisi fisiologis tikus, hal ini yang menyebabkan kenaikan kadar asam urat Tikus berfariasi.

Hasil pengukuran kadar asam urat tikus pada hari ke 9, hari ke 12, dan hari ke 15 menunjukan bahwa kadar asam urat tikus hiperurisemia kelompok kontrol negatif berada pada rata-rata 5,00-5,33, pada kontrol positif berada pada rata-rata 2,17-2,83mg/dL, pada kelompok dosis 50 mg berada pada rata-rata $2,57-3,33 \mathrm{mg} / \mathrm{dL}$, pada kelompok dosis $100 \mathrm{mg}$ berada pada rata-rata $2,87-3,40 \mathrm{mg} / \mathrm{dL}$, dan pada kelompok dosis $200 \mathrm{mg}$ berada pada ratarata $2,30-3,27 \mathrm{mg} / \mathrm{dL}$. Untuk lebih jelasnya mengenai peningkatan dan penurunan

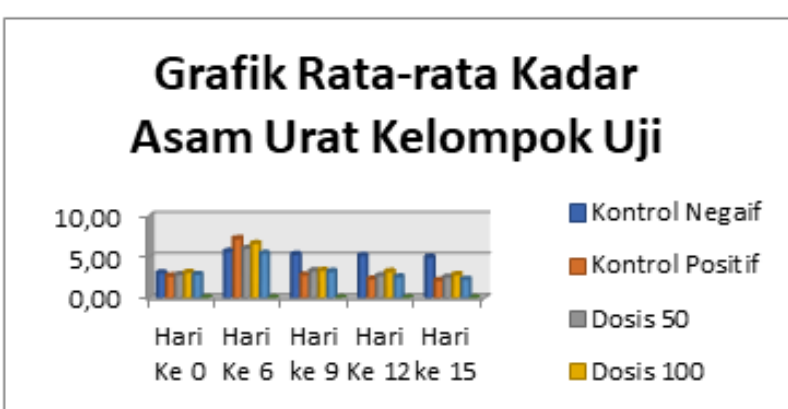

Gambar 1. Grafik Rata-rata peningkatan dan penurunan kadar

kadar Asam urat Tikus selama perlakuan dapat dilihat pada grafik dibawah ini.

Dari grafik di atas menunjukan bahwa kadar asam urat tikus setiap kelompok mengalami penurunan, namun kadar asam urat tikus kelompok kontrol negatif lebih tinggi dari pada kelompok kontrol positif dan 3 kelompok variasi dosis, kadar asam urat tikus kelompok ini masih termasuk dalam kondisi hiperurisemia. Hasil tersebut menunjukan bahwa CMC tidak begitu berpengaruh dalam penurunan kadar asam urat tikus, sedangkan hasil pengukuran kadar asam urat tikus kelompok kontrol positif dan 3 kelompok variasi dosis menunjukan adanya penurunan kadar asam urat yang signifikan.

Tabel 3. Rata-rata penurunan kadar asam urat tikus

\begin{tabular}{cc}
\hline Kelompok & $\begin{array}{c}\text { Rata-rata Pengukuran } \\
\text { Asam Urat Tikus (mg/dL) }\end{array}$ \\
\hline $\begin{array}{c}\text { Kontrol } \\
\text { Negatif }\end{array}$ & 5,18 \\
$\begin{array}{c}\text { Kontrol } \\
\text { positif }\end{array}$ & 2,44 \\
Dosis 1 & \\
Dosis 2 & 2,89 \\
Dosis 3 & 3,18 \\
\hline
\end{tabular}

Dari tabel 3 dapat dilihat bahwa dalam penelitian ini penurunan kadar asam urat yang signifikan terjadi pada 
kelompok kontrol positif kemudian diikuti oleh 3 kelompok variasi dosis

Dijelaskan bahwa kelompok kontrol positif yang diberikan allopurinol memiliki penurunan kadar asam urat paling besar dibandingkan dengan perlakuan eksrak etanol tumbuhan suruhan. Pemilihan allopurinol sebagai kontrol positif atau pembanding dianggap tepat, karena allopurinol bekerja dengan menghambat xantin oksidase. Allopurinol menghambat sintesis purin yang merupakan prekusor xantin. Allopurinol sendiri mengalami biotransformasi oleh enzim xantin oksidase menjadi aloxanthin yang masa paruhnya lebih panjang dari allopurinol (Wilmana, 2005). Selanjutnya di ikuti dengan kelompok variasi dosis $200 \mathrm{mg}$, kemudian dosis $50 \mathrm{mg}$, dan dosis $100 \mathrm{mg}$. Hal ini menunjukan ekstrak etanol tumbuhan suruhan dapat memberikan efek penurunan kadar asam urat dan Dosis 200 mg ekstrak etanol tumbuhan Suruhan merupakan dosis optimum dalam menurunkan kadar asam urat. Oleh karena itu, ekstrak etanol tumbuhan suruhan dapat direkomendasikan sebagai obat alternatif untuk menurunkan asam urat.

Kemampuan ekstrak etanol tumbuhan suruhan dalam menurunkan kadar asam urat darah tikus, di duga disebabkan oleh senyawa flavonoid yang terdapat dalam ekstrak tumbuhan tersebut. Nwokocah et al (2012), melaporkan bahwa tumbuhan Suruhan mengandung senyawa Flavonoid . Senyawa Flavonoid dapat bersifat sebagai antioksidan dengan mekanisme kerjanya adalah dengan cara menghambat aktivitas xantin oksidase pada basa purin sehingga akan menurunkan kadar asam urat. Khan (2008), menyatakan pada tumbuhan suruhan juga terdapat senyawa saponin.
Chen (2006), dalam penelitiannya menyatakan bahwa senyawa saponin juga dapat menurunkan kadar asam urat.

Untuk memperoleh data yang lebih spesifik mengenai antihiperurisemia ekstrak etanol tumbuhan suruhan dan allopurinol maka dilakukan pengolahan data dengan menggunakan SPSS.

Uji statistik yang pertama adalah Uji Levene untuk melihat homogenitas data menunjukan bahwa data terdistribusi homogen dan untuk uji analisis varian (ANNOVA) menunjukan bahwa data memiliki varian yang sama atau bervariasi homogen ( $\mathrm{P} \geq 0.05)$, dilanjutkan dengan uji kenormalan data (One-Sample kolmogorove Smirnov-test) menunjukan bahwa data terdistribusi normal ( $\mathrm{P} \geq 0.05)$, dilanjutkan dengan uji kruskal wallis menunjukan bahwa tidak terdapat perbedaan bermakna antar kelompok perlakuan $(\mathrm{P} \geq 0.05)$. Hal ini menunjukan bahwa ekstrak etanol Tumbuhan Suruhan memiliki efektivitas terhadap penurunan kadar asam urat tikus, karena dapat memberikan efek penurunan asam urat yang tidak berbeda secara bermakna dengan allopurinol.

\section{KESIMPULAN}

Ekstrak etanol tumbuhan suruhan (Peperomia pellucida L.Kunth) dapat menurunkan kadar asam urat dengan dosis $200 \mathrm{mg}$ merupakan dosis optimum dalam menurunkan kadar asam urat dibandingkan dengan dosis $100 \mathrm{mg}$ dan dosis $50 \mathrm{mg}$.

\section{SARAN}

Perlu dilakukan penelitian lebih lanjut untuk mengetahui senyawa aktif dari tumbuhan suruhan (Peperomia pellucida L.Kunth) yang lebih spesifik dan yang 
lebih berperan dalam penurunan kadar asam urat.

\section{DAFTAR PUSTAKA}

Artini NPR, Wahyuni. 2012. Ekstrak Daun Sirsak (Annona Muricata L.) terhadap penurunan Kadar Asam Urat Darah Tikus Wistar. Jurnal Kimia Fakultas MIPA Universitas Udayana. Vol 6: 121-137.

Aryadi. 2007. Uji Ekstrak Methanol Daun Kapel(Sthelechocarpus burahol) terhadap aktivitas Enzim Xantin Oksidase [Skripsi]. Fakultas Farmasi UGM, Yogyakarta.

Azizahwati, Wiryowidagdo, Kartika. 2005, Efek Penurunan Asam Urat Dalam Darah Pada Tikus Jantan dari Rebusan Akar Tanaman Akar Kucing (Acalypha Indica Linn). Jurnal Bahan Alam Indonesia. Vol 4 : 1.

Chen., Wei., Xu., 2006. Effect and mechanism of total saponin of dioscorea on animal Experimental Hypreuricemia. Journal China Medicine 34 : 1

Dalimartha. 2014. Tumbuhan Sakti. Penebar Swadaya, Jakarta.

Fahri. 2004. Kadar Glukosa dan Kadar Kolestrol Tikus Putih(Rattus Norvegicus). Hiperglikemik setelah pemberian ekstrak metanol akar meniran (Phylanthus niruri. L). [skripsi]. FMIPA UNS, Surakarta.

Hakim, L.2012. Metode Fitokimia: Penentuan Cara Menganalisis Tumbuhan. Universitas Muhamadiyah, Purwokerto.

Khan. 2012. Evolution of flavonoids and divrse Antioxidant Activities of Sonchus Arvensis. Chemistry Central Journal Vol 6: 126.
Kusmiyati. 2008. Kadar Asam Urat Serum dan urin Tikus Putih Hiperurikemia setelah pemberian Jus Kentang (Solanum Tuberosum L.).[Skripsi]. Jurusan Biologi Fakultas MIPA UNS, Surakarta.

Misra H. 2012. Study of Extraction and HPTLC - UV Methode for Estimation of caffeine in marketed tea (Camelia sinessis) Granules. Internasional Journal of green Pharmacy.

Nwokocah., D. U. Owu., Kinlocke., Murray., Delgoda., Mecalla., and L.Young. 202. Hypotensive effect of PeperomiaPellucida and interactions between human cytochrome P450 Enzyms. Medicanal and aromatic Plants 1: 5 .

Wilmana. 2005. Farmakologi dan Terapi. Gaya Baru, Jakarta. 